\title{
Evaluation of Low Back Pain and Its Effects in Health Employees
}

\section{Sağıı Çalışanlarında Bel Ağrısı ve Etkilerinin Değerlendirilmesi}

\author{
๑ İlknur Demir, ๑ Güzin Zeren Öztürk
}

University of Health Sciences Turkey, Şişli Hamidiye Etfal Training and Research Hospital, Clinic of Family Medicine, İstanbul, Turkey

Background: It is reported that more than $80 \%$ of the world's population experience low back pain at any time in their lives. Low back pain is a common cause of morbidity among health employees. Health employees are a high-risk group in terms of low back pain due to difficult physical workload and ergonomic problems. The aim of our study was to evaluate low back pain and its effects in health employees.

Materials and Methods: The study was conducted in April 2017 at Şişli Hamidiye Etfal Research and Training Hospital. The questionnaire form designed by the researcher and the Oswetry Scale were applied to the participants by face to face inquiry method. The statistical program SPSS was used to analyze data.

Results: Of the participants, 39.16\% ( $n=103)$ had low back pain. Participants were divided into two groups as those with and without back pain. Age, gender, mean body mass index (BMI), BMI classification, educational status, smoking status and working time in the profession were found to be statistically significant between the two groups $(p<0.005)$. The mean Oswestry Scale score of individuals with low back pain was $19.38 \pm 11$.17. Participants were divided into two groups according to their level of exposure as mild $(0-40 \%)$ and severe $(\geqslant 40 \%)$, and related factors were examined. A significant relationship was found with the mean BMI, BMI classification and profession ( $p<0.005)$.

Conclusion: Two-fifths of the healthcare professionals had low back pain. During the periodic examinations of healthcare personnel, low back pain should be questioned. These groups should be examined in more detail and exercise recommendations should be made for smoking cessation, weight loss and muscle strengthening, since they are common in women, those with high school or lower education, those who spend a longer time in the profession, and those who are smokers, overweight and obese.

Keywords: Low back pain, hospital personel, risk factors

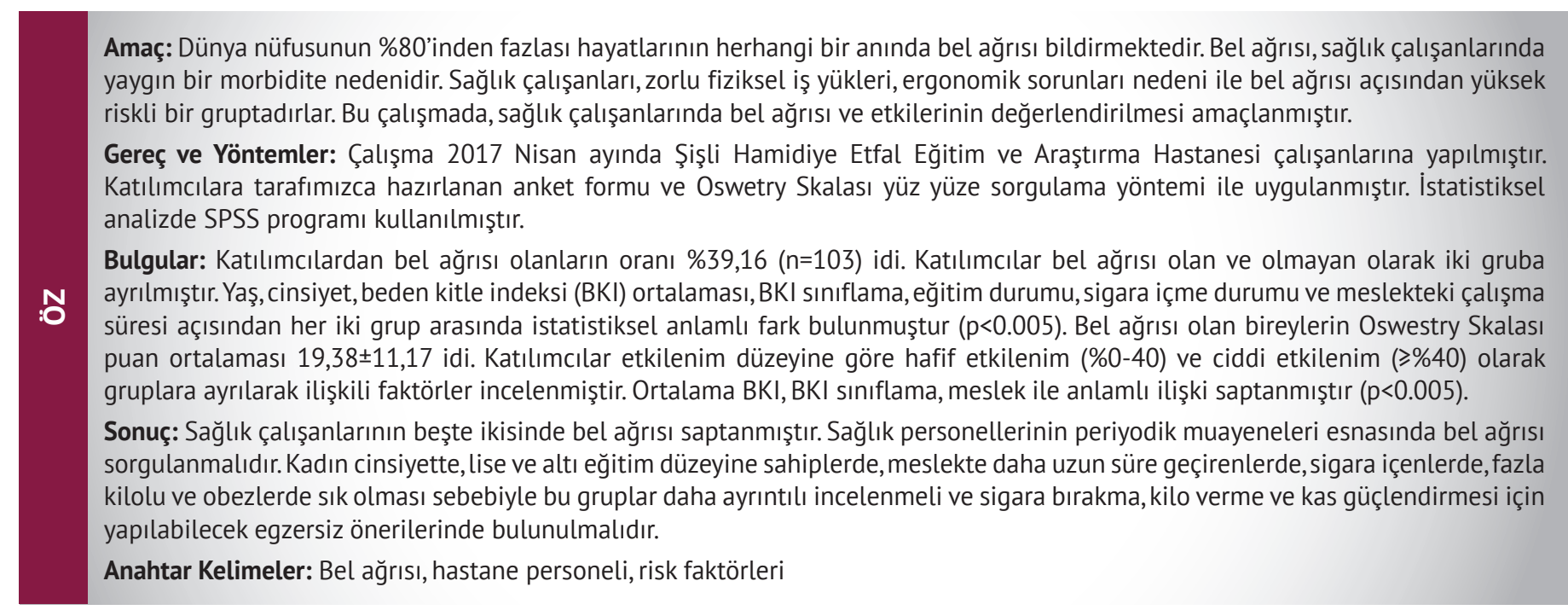

Address for Correspondence: Ilknur Demir, University of Health Sciences Turkey, Şişli Hamidiye Etfal Training and Research Hospital, Clinic of Family Medicine, İstanbul, Turkey Phone: +90 2123735000 E-mail: ilknurdemir25@gmail.com ORCID ID: orcid.org/0000-0003-0055-7186

Received: 07.05.2021 Accepted: 11.06.2021 


\section{Introduction}

Low back pain is located in the lumbar region between the last costal rib and the gluteal curve (1). It is reported that more than $80 \%$ of the world's population experience low back pain at any time in their lives $(2,3)$. However, as most low back pain resolves within the first two weeks without any treatment, individuals with low back pain lasting longer than 2 weeks and/or requiring treatment are affected by low back pain as a result of functional incapacity $(4,5)$.

Epidemiological studies show that there are a variety of risk factors affecting the incidence and prevalence of low back pain. Personal risk factors for low back pain may be listed as age, gender, occupation, body mass index (BMI), family history, smoking, alcohol intake and physical activity levels (6). A person's occupation and working conditions may cause the occurrence of low back pain.

Low back pain is a common cause of morbidity among health employees (2). Health employees constitute a highrisk group in terms of low back pain due to difficult physical workload (long working hours, shift work, being on call, etc.) and ergonomic problems (transferring patients, repositioning patients, frequent bending, lifting heavy loads, pulling and pushing, remaining in the same position for long periods, repeated movements) $(7,8,9)$.

The aim of our study was to evaluate low back pain and its effects in health employees.

\section{Material and Methods}

\section{Research Population and Sample}

The research was a single-center descriptive study. The study was performed with employees in Şişli Hamidiye Etfal Training and Research Hospital from April 01, 2017 to April 30, 2017. At the time of the study, the hospital employed a total of 2,318 people, with 694 doctors, 790 nurses (nurses, midwives, emergency medicine technicians), and 834 other personnel (data entry, security, cleaning). Layered sampling was applied with $95 \%$ confidence interval and the sample size was calculated as 263 people (doctors: 79 , nurses: 89 , others: 95). Participants were included in the study after obtaining verbal consent.

Those with congenital hip dislocation, spine fracture history, known psychiatric or neurologic disease increasing low back pain risk, different length legs for any reason or inflammatory low back pain were not included in the study. Ethics committee permission was granted by Şişli Hamidiye Etfal Research and Training Hospital Ethics Committee (date: 07 March 2017, decision number: 1436).

\section{Data Collection Tools}

Socio-demographic data for participants, BMI calculations and the presence of low back pain were questioned. Individuals with low back pain lasting longer than 2 weeks and/or requiring treatment were assessed as having low back pain, and participants were divided into two groups as those with and without low back pain. Moreover, relevant factors were evaluated.

\section{Oswestry Scale}

Participants with low back pain were applied the Oswestry Scale (OS) to determine effect levels. This scale was published by Fairbank and Pynsent (10) with the aim of assessing functional capacity of individuals. Turkish validity and reliability were examined by Yakut et al. (11) and the scale was prepared for use by Akbay (12). The OS comprises ten subgroups (pain intensity, self-care, lifting-carrying, walking, sitting, standing, sleep, traveling and social life). Points vary from 0 to 50 and the patient score is assessed with the formula: Total score = (points received by participant $/$ maximum possible points) $\times 100$. Levels of effect increase as total score increases.

Accordingly, results are grouped as;

- 0-20\% low back pain does not cause a significant problem in the patient's life.

- 20-40\% low back pain mildly restricts the patient's daily life.

- 40-60\% low back pain significantly restricts the patient's daily life.

- $60-80 \%$ low back pain fully restricts the patient's daily life.

- 80-100\% bedridden.

Participants in the study were divided into two groups as those with mild level of effects (0-40\%) and those with serious effects ( $\geqslant 40 \%$ ), and associated factors were investigated.

\section{Statistical Analysis}

The SPSS 20.0 program was used in the study. Descriptive statistics were given as number and percentage for categoric variables and as mean, standard deviation, minimum and maximum for numerical variables. Numerical variables were compared in two independent groups with the Student's t-test when normal distribution conditions were present and with the Mann-Whitney $U$ test when normal distribution conditions were not present. Rates in independent groups were compared with the chi-square analysis. Values of $p<0.05$ were accepted as statistically significant.

\section{Results}

The ages of the 263 people participating in the study varied from 20 to 65 years, with the mean age of $33.89 \pm 9.04$ 
years. Of participants, $58.55 \%$ were women $(n=154)$ and $41.45 \%$ were men $(n=109)$. Participants comprised higher rates of married individuals $(51.33 \%, \mathrm{n}=135)$. The mean $\mathrm{BMI}$ of participants was $38 \pm 4.12(15.62-45.72)$ and $9.3 \%$ were obese $(n=22)$. There were 145 participants who did not smoke (55.13\%). For all participants, the mean working duration in their profession was $9.16 \pm 7.91$ years (1-36).

Among the participants, 39.16\% had low back pain ( $n=103)$. Participants were divided into two groups as those with and without low back pain, and relevant factors were investigated (Table 1). Accordingly, there were statistically significant differences found between the two groups in terms of age, gender, mean BMI, BMI classification, educational status, smoking habit and professional working duration $(p=0.002$, $p=0.049, p=0,001, p<0.001, p=0.019, p=0.003$, and $p=0.007$, respectively). As age, weight, mean $\mathrm{BMI}$, and professional working duration increased, the experience of low back pain increased. Additionally, educational level lower than high school, smoking rate and the rate of being female gender were significantly higher.

The mean OS points of individuals with low back pain were $19.38 \pm 11.17$ (1-48). The effect status according to OS is given in Figure 1, with most people $(31.09 \%, n=32)$ experiencing mild limitation of daily life. Investigation of related factors when participants were divided into two groups according to mild effect (0-40\%) and severe effect $(\geqslant 40 \%)$ is shown in Table 2 . There were significant associations identified for mean BMI, BMI classification and profession ( $p=0.013, p=0.017$, and $p=0.029$, respectively).

\section{Discussion}

Health employees were identified to experience low back pain in any period of life at rates of $46.30-84 \%$ in the

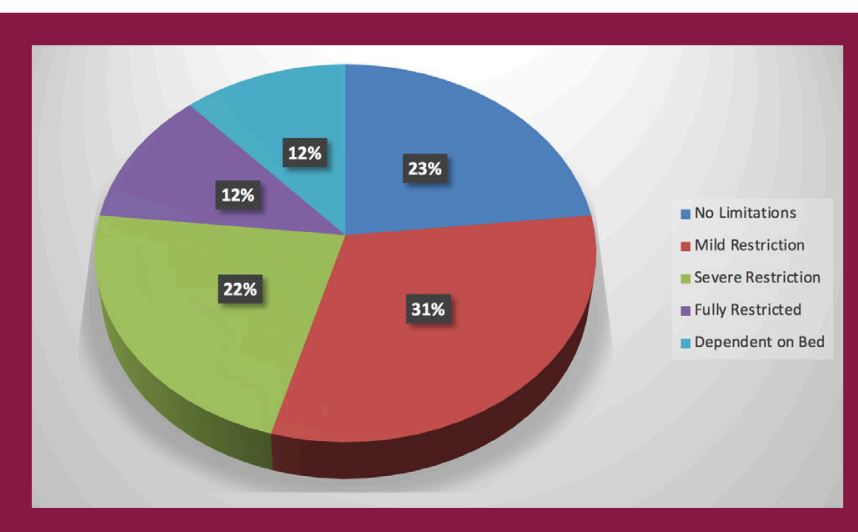

Figure 1. Affected states according to the Oswestry Scale

Table 1. Participants' low back pain status and evaluation of related factors

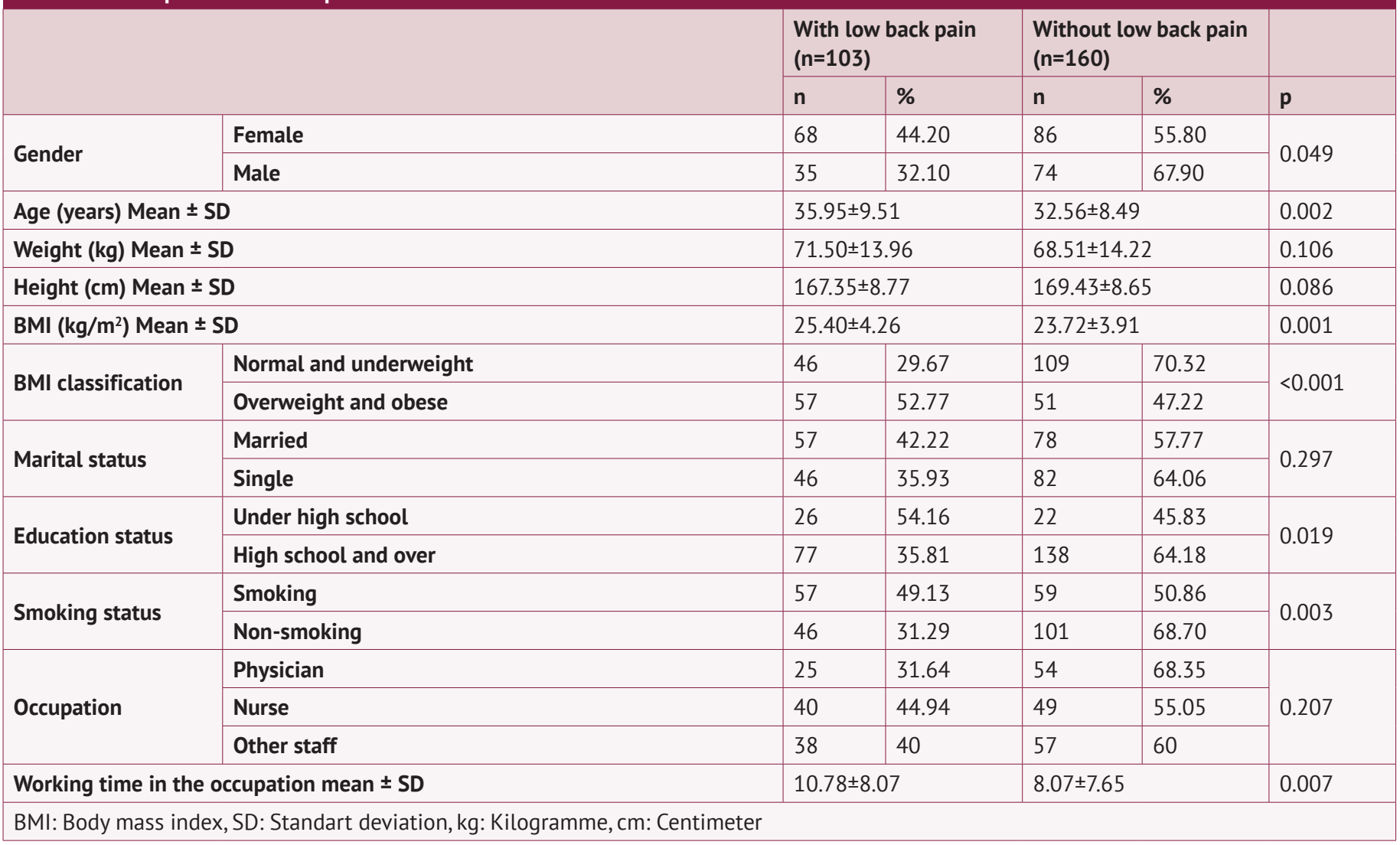


Table 2. Evaluation of the affected participants with low back pain and related factors

\begin{tabular}{|c|c|c|c|c|c|c|}
\hline & & $\begin{array}{l}\text { Tho } \\
\text { effe } \\
(0 \% \\
\text { ( }=\end{array}$ & Id level of & $\begin{array}{l}\text { Tho } \\
\text { effe } \\
(\geqslant 4 \\
\text { ( } n=\end{array}$ & erious & \\
\hline Gender & Female & 34 & 50 & 34 & 50 & 015 \\
\hline Gerluet & Male & 22 & 62.9 & 13 & 37.1 & $0.21 J$ \\
\hline Weight (kg) Mean & & 70.8 & & 72.2 & & 0.222 \\
\hline Height $(\mathrm{cm})$ Mean & & 168 & & 165 & & 0.056 \\
\hline BMI $\left(\mathrm{kg} / \mathrm{m}^{2}\right)$ Mean & & 24. & & 26.2 & & 0.013 \\
\hline DMI - Incrifiention & Normal and underweight & 31 & 55.4 & 15 & 44.6 & 0017 \\
\hline Fducation ctatuc & Under high school & 10 & 38.5 & 16 & 61.5 & 0060 \\
\hline Euncadionil stalus & High school and over & 46 & 59.7 & 31 & 40.3 & 0.000 \\
\hline Smoking ctatuc & Smoking & 32 & 56.1 & 25 & 43.9 & 0688 \\
\hline 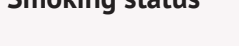 & Non-smoking & 24 & 52.2 & 22 & 47.8 & 0.000 \\
\hline & Physician & 19 & 76 & 6 & 24 & \\
\hline Occupation & Nurse & 21 & 52.5 & 19 & 47.5 & 0.029 \\
\hline & Other staff & 16 & 42.1 & 22 & 57.9 & \\
\hline $\begin{array}{l}\text { Working time in th } \\
\text { mean } \pm S D\end{array}$ & & 10. & & 11. & & 0.130 \\
\hline
\end{tabular}

literature $(9,13,14,15,16,17,18,19)$. The rate in our study was $39.16 \%$, which may be due to the fact that our study only questioned individuals with low back pain lasting more than 2 weeks and/or requiring treatment and not in any period of life.

In the literature, low back pain can be observed in any age group, though it is stated to be higher in the group with active working life aged from 20 to 55 years $(9,20)$. In the study, the mean age of individuals with low back pain was compatible with this age group and higher than those without low back pain. The identification of low back pain at significantly higher rates in the female gender is consistent with the literature; women may be exposed to higher rates than men due to lifelong hormonal variations (pregnancy, menopause, etc.) $(9,13,21)$. The observation of higher rates of low back pain in those with educational level of high school or lower may be due to increased awareness of the use of body mechanisms and protective precautions as a part of healthy life and movement in accordance with this in those with increased educational level (20).

In our study, experience of low back pain with longer duration in the profession was statistically significant. As the duration of working in a profession increases, this may cause increased duration of exposure to risk factors involved in the profession. In fact, Arasan et al. (15) found lifelong and point prevalence of low back pain was increased duration of employment in a profession. Deksisa Abebe et al. (22) observed that health employees working longer than 12 years had higher prevalence of low back pain compared to those employed for durations less than 12 years.

Health employees are reported to smoke at different rates from 13.9 to $46.3 \%(13,14,23)$. In this study, the smoking rate was $38 \%$. In the literature, just as there are studies showing a correlation between smoking and low back pain $(21,23,24,25)$, there are studies showing no correlation $(15,20,26)$. Studies proposing no effect of smoking on low back pain give reasons such as nicotine's analgesic effect and depression-reducing effects of nicotine; studies stating that there is an association indicate that smoking increases the risk of low back pain incidence due to disrupting nutrition of the vertebral disk, making the disk more susceptible to external factors, and reducing blood perfusion in the spine and muscles due to vasoconstriction caused by nicotine in cigarettes (23). In 
our study, a significant association was identified between smoking and experience of low back pain and there is a need for advanced research about this topic.

A meta-analysis revealed a significant correlation between BMI and low back pain (27). In the study, low back pain had significantly higher rates in overweight and obese participants and the mean BMI of the group with low back pain was identified to be higher. Due to the additional weight carried by overweight and obese individuals, they may have weak back and abdominal muscles (28). This situation increases stress in the musculo-skeletal system $(28,29)$. Additionally, obesity causes higher compressive forces on the lumbar spine during a variety of movements, which may cause increased mechanical load on the spine $(22,28,29)$.

In the study, most health employees with low back pain had mild degree of restriction of daily life activities according to the mean OS; however, a considerable portion (9.60\%) was bedridden. A study by Güzel and Altındağ (30) found $41.7 \%$ of participants had no limitation, while $5.5 \%$ had severe restriction. Solak Kabataş et al. (31) identified the rate of $40.0 \%$ for mild effect and the rate of $3.3 \%$ for severe effect. This situation illustrates that low back pain may affect health employees to different degrees and at a variety of rates; in fact, the reality is that it may cause severe functional incapacity leading to being bedridden. In terms of profession, other personnel being more affected may be due to the excess of bodily labor.

In the study, those severely affected by low back pain had higher mean $\mathrm{BMl}$; the rate of severe effect among overweight and obese participants was identified to be significantly high. Obesity on its own is related to increased production of cytokines and acute phase reactants and activation of proinflammatory pathways, which may lead to delayed healing in this situation $(32,33)$.

\section{Conclusion}

In conclusion, two out of five health employees were identified to have low back pain. Low back pain was observed more frequently in those who had female gender, education level of high school or lower, and longer duration in their profession, who smoked, and who were overweight or obese. It was revealed that being overweight and obese and working as other health personnel caused severe degree of effect of low back pain.

In light of these results, it may be concluded that it is necessary to inquire about low back pain during periodic examinations of health personnel. We think it is necessary to investigate groups who have female gender, high school or lower educational level, longer period in the profession, who are smokers, and those who are overweight and obese in more detail due to higher incidence and to recommend quitting smoking, losing weight and exercises for muscle strengthening.

\section{Ethics}

Ethics Committee Approval: Ethics committee permission was granted by Şişli Hamidiye Etfal Training and Research Hospital Ethics Committee (date: 07 March 2017, decision number: 1436).

Informed Consent: Participants were included in the study after obtaining verbal consent.

Peer-review: Externally and internally peer-reviewed.

\section{Authorship Contributions}

Surgical and Medical Practices: I.D., G.Z.Ö., Concept: I.D., G.Z.Ö., Design: I.D., G.Z.Ö., Data Collection or Processing: I.D., Analysis or Interpretation: I.D., G.Z.Ö., Literature Search: I.D., G.Z.Ö., Writing: I.D., G.Z.Ö.

Conflict of Interest: No conflict of interest was declared by the authors.

Financial Disclosure: The authors declared that this study received no financial support.

\section{References}

1. Cargnin ZA, Schneider DG, Vargas MAO, Machado RR. Non-specific low back pain and its relation to the nursing work process. Rev Lat Am Enfermagem. 2019;27:e3172. doi: 10.1590/1518-8345.2915.3172. [Crossref]

2. Sanjoy SS, Ahsan GU, Nabi H, Joy ZF, Hossain A. Occupational factors and low back pain: a cross-sectional study of Bangladeshi female nurses. BMC Res Notes. 2017;10:173. [Crossref]

3. Illés ST. A derékfájás: mikor és mit tegyünk? [Low back pain: when and what to do]. Orv Hetil. 2015;156:1315-1320. (Hungarian) [Crossref]

4. Akyüz GD. Bel Ağrılarında Tanı, Ayırıcı Tanı ve Baş Etme Stratejileri. Uluslararası Katılımlı Türk Romatoloji Kongresi,Antalya, Türkiye. 2019;133. [Crossref]

5. Oğuz S, Kaptan H. Low back pain in working life. Turkish Med Assoc Occup Heal Saf Mag. 2005;45-48. [Crossref]

6. Şimşek Ş, Yağci N, Şenol H. Prevalence of and risk factors for low back pain among healthcare workers in Denizli. Pain. 2017;29:71-78. [Crossref]

7. Kostanoğlu A, Şüheda Gözaydınoğlu TMK. Investıgatıon Of Nonspecıfıc Low Back Paın In Hospital And Home Health Care Professıonals. acta medica nicomedia. 2020;3(1):1-19. [Crossref]

8. Ando S, Ono Y, Shimaoka M, Hiruta S, Hattori Y, Hori F, et al. Associations of self estimated workloads with musculoskeletal symptoms among hospital nurses. Occup Environ Med. 2000;57:211-216. [Crossref]

9. Awosan KJ, Yikawe SS, Oche OM, Oboirien M. Prevalence, perception and correlates of low back pain among healthcare workers in tertiary health institutions in Sokoto, Nigeria. Ghana Med J. 2017;51:164-174. [Crossref]

10. Fairbank JC, Pynsent PB. The Oswestry disability index. Spine (Phila Pa 1976). 2000;25:2940-2953.

11. Yakut E, Düger T, Öksüz Ç, Yörükan S, Üreten K, Turan D, et al. Validation of the Turkish version of the oswestry disability index for patients with low back pain. Spine (Phila Pa 1976). 2004;29:581-585. [Crossref]

12. Akbay A. Oswestry Scale. Last Accessed Date: 02.01.2021. Available from: http://www.spinetr.com/Uploads/files/skor/Oswestry.pdf [Crossref]

13. Leblebicioğlu H, Bayraktar D, Khorshtd L, Sarıtaş N. Functional Deficiency Related Low Back Pain Among Nurses Working in a State Hospital and the Associated Factors. Int Ref J Nurs Res. 2018;0:61-81. [Crossref] 
14. Terzi R, Altin F. The prevalence of low back pain in hospital staff and its relationship with chronic fatigue syndrome and occupational factors. Pain. 2015;27:149-154. [Crossref]

15. Arasan F. Determination of the prevalence of low back pain among nurses working in a university hospital Abstract. Cerrahpaşa Tıp Derg. 2009;40:136-143. [Crossref]

16. Airaksinen O, Brox JI, Cedraschi C, Hildebrandt J, Klaber-Moffett J, Kovacs F, et al; COST B13 Working Group on Guidelines for Chronic Low Back Pain. Chapter 4. European guidelines for the management of chronic nonspecific low back pain. Eur Spine J. 2006 Mar;15 Suppl 2(Suppl 2):S192-300. doi: 10.1007/s00586-006-1072-1. [Crossref]

17. Shieh SH, Sung FC, Su CH, Tsai Y, Hsieh VC. Increased low back pain risk in nurses with high workload for patient care: a questionnaire survey. Taiwan J Obstet Gynecol. 2016;55:525-529. [Crossref]

18. Trinkoff AM, Lipscomb JA, Geiger-Brown J, Brady B. Musculoskeletal problems of the neck, shoulder, and back and functional consequences in nurses. Am J Ind Med. 2002;41:170-178. [Crossref]

19. Cunningham C, Flynn T,Blake C. Low back pain and occupation among Irish health service workers. Occup Med (Lond). 2006;56:447-454. [Crossref]

20. Yilmaz E, Özkan S. Determination of the Prevalence of Low Back Pain Among Nurses Working in Hospitals. Turk J Phys Med Rehab. 2008;54:812. [Crossref]

21. Altinel L, Köse KC, Ergan V, Işik C,Aksoy Y, Ozdemir A, et al. [The prevalence of low back pain and risk factors among adult population in Afyon region, Turkey]. Acta Orthop Traumatol Turc. 2008:42:328-333. (Turkish) [Crossref]

22. Deksisa Abebe A. Prevalence of low back pain and associated risk factors among Adama Hospital Medical College Staff, Ethiopia. Eur J Prev Med. 2015;3:188-192. [Crossref]

23. Urgan U, Hamzaoğlu O. Examination of the frequency of low back pain and the factors affecting low back pain among the assistants working at
Kocaeli University Faculty of Medicine. Occup Heal Saf J. 2016;16:49-56. [Crossref]

24. Esen ES, Toprak D. Evaluation of the Prevalence and Associated Factors of Low Back Pain. Ankara Med J. 2018;4:460-469. [Crossref]

25. Ayvat PÜ,Aydin ON, Oğurlu M. Risk factors associated with lower back pain in the Polyclinic of Algology. Pain. 2012;24:165-170. [Crossref]

26. Albayrak I, Nilay Ş, Karahan AY, Hatice U, Üniversitesi S, Meram T, et al. The relation of smoking with the low back pain. Gen Med J. 2010;20:55-59. [Crossref]

27. Shiri R, Karppinen J, Leino-Arjas P, Solovieva S, Viikari-Juntura E. The association between obesity and low back pain: a meta-analysis. Am J Epidemiol. 2010;171:135-154. [Crossref]

28. Hu HY, Chou YJ, Chou P, Chen LK, Huang N. Association between obesity and injury among Taiwanese adults. Int J Obes (Lond). 2009;33:878-884. [Crossref]

29. Alnaami I, Awadalla NJ, Alkhairy M, Alburidy S, Alqarni A, Algarni A, et al. Prevalence and factors associated with low back pain among health care workers in southwestern Saudi Arabia. BMC Musculoskelet Disord. 2019;20:56. [Crossref]

30. Güzel HÇ. Altındağ Ö. Relationship between low back pain, neck pain, psychical situation and quality of life and the burnout syndrome in hospital workers. Cumhur Üniv Sağ Bil Enst Derg. 2021;1:36-45. [Crossref]

31. Solak Kabataş M, Kocuk M, Küçükler Ö. Evaluation of frequency and factors affecting low back pain in health care workers. Fırat Üniversitesi Sağlık Bilim Tip Derg. 2012;2:65-72. [Crossref]

32. Tilg $\mathrm{H}$, Moschen AR. Adipocytokines: mediators linking adipose tissue, inflammation and immunity. Nat Rev Immunol. 2006;6:772-783. [Crossref]

33. Demirci Ş, Gün C. Adipose tissue and some proteins released from adipose tissue. MAKÜ Sag Bil Enst Derg. 2017;5:155-179. [Crossref] 